\begin{tabular}{|l|l|l||}
\hline \multicolumn{2}{|c|}{ PublisherInfo } \\
\hline \hline PublisherName & $:$ & Palgrave Macmillan UK \\
\hline \hline PublisherLocation & $:$ & London \\
\hline \hline PublisherImprintName & $:$ & Palgrave Macmillan \\
\hline \hline
\end{tabular}

\title{
Regional economic indicators, May 2007, with a focus on sub- regional household income
}

\begin{tabular}{|l|l|l||}
\hline \multicolumn{3}{|c|}{ ArticleInfo } \\
\hline \hline ArticleDOI & $:$ & $10.1057 /$ palgrave.elmr.1410077 \\
\hline \hline ArticleCategory & $:$ & Feature \\
\hline \hline ArticleFirstPage & $:$ & 60 \\
\hline \hline ArticleLastPage & $:$ & 70 \\
\hline \hline & & RegistrationDate $: 2007-5-18$ \\
ArticleHistory & $:$ & OnlineDate $\quad: 2007-5-18$ \\
& $:$ & Crown copyright2007 \\
\hline \hline ArticleCopyright &
\end{tabular}




\section{Claire Swadkin, ${ }^{\text {Aff1 }}$}

David Hastings, ${ }^{\text {Aff1 }}$

\section{Compiles information covering the nine English Government Office Regions, Northern Ireland, Scotland and Wales for the regional economic indicators.}

This quarter, regional economic indicators (REI) focuses on sub-regional household income in light of the latest published data. The headline indicators provide the underlying picture of regional economic performance, productivity and welfare. Labour market data and indicators of factors that drive productivity are also included. This article covers the nine English Government Office regions, Northern Ireland, Scotland and Wales: the European Nomenclature of Units for Territorial Statistics (NUTS) level 1 regions of the UK. The term 'region' is used for convenience.

\section{Misc}

The Full Text of this article can be found on the National Statistics website (http://www.statistics.gov.uk/elmr/05_07/downloads/ELMR_0507REI.pdf). 